\title{
Losing Sight, Gaining Insight: Blindness and the Romantic Vision in Grimm's "Rapunzel"
}

\author{
Anna Wing Bo TSO*
}

Associate professor of English, School of Arts and Social Sciences, The Open University of Hong Kong, 30 Good Shepherd Street, Ho Man Tin, Kowloon, Hong Kong, China

Corresponding Author: Anna Wing Bo TSO, E-mail: atso@ouhk.edu.hk

\author{
ARTICLE INFO \\ Article history \\ Received: February 19, 2019 \\ Accepted: May 26, 2019 \\ Published: June 30, 2019 \\ Volume: 10 Issue: 3 \\ Advance access: May 2019 \\ Conflicts of interest: None \\ Funding: None \\ Key words: \\ Anti-Enlightenment, \\ Anti-Rationalism, \\ Blindness, \\ Brothers Grimm, \\ Female Spirit, \\ German Romanticism, \\ Grimm's Rapunzel
}

\begin{abstract}
In Brothers' Grimm's fairy tales, the motif of blindness occurs quite frequently, each time with a different symbolic meaning. In "Hansel and Gretel", blindness is represented as a body deformity, an abject feature of the red-eyed, half-blind cannibalistic witch who lives in the candy house in the middle of the forest, while in "Cinderella", blindness becomes more: a brutal punishment for wrongdoings, such as when: the wickedly unkind stepsisters' eyes are pecked out by pigeons as they are on the way to the wedding of the Cinderella and her handsome prince. Yet, in "Rapunzel", blindness is not meant to be an abject feature nor a direct punishment. Rather, it opens the door to the Romantic vision and spirit. Through studying the earlier versions of the Rapunzel story and the Grimm's later version, this paper explores how blindness represents the limitations of logic and reason and, through embracing the beautiful power of the female sensibility, welcomes the rebirth of insight, faith and Romantic sentiments.
\end{abstract}

\section{INTRODUCTION: BLINDNESS IN "RAPUNZEL"}

For centuries, the motif of blindness has appeared in literature of many cultures. From early literature such as $O e$ dipus Rex, the Holy Bible, and folklore, to more modern books such as Helen Keller's The Story of My Life, blindness and sightless people are represented in many different ways. According to Jenigan, blindness often occurs in literature as: (1) a compensatory or miraculous power; (2) a total tragedy; (3) foolishness and helplessness; (4) unrelieved wickedness and evil; (5) a perfect virtue; (6) a punishment for sin; (7) abnormality or dehumanization; (8) purification, or (9) a symbol or a parable. Blindness also occurs in many Grimm's fairytales, such as "Hansel and Gretel" and "Cinderella". However, unlike most Grimm's fairytales where blindness is portrayed as a punishment for wickedness or an abject feature "to reaffirm norm and order" (Tso 223), in Grimm's "Rapunzel" (1812/1819/1857), the protagonist who loses his eyesight is the prince who has fallen in love with young Rapunzel, a maiden trapped in the tower by a witch. What is at issue is: the prince's blindness and his suffering were the Grimm Brothers' creation. In the earlier versions of "Rapunzel", no one is blind, and there is no prince. Why did the Grimm Brothers make changes to the plot? What are the implications of the prince's blindness? With the aim to reveal the symbolic meaning of blindness in the story this paper examines the original Rapunzel story and its influences and compares that with Grimm's version and the time period in which it was rewritten, from 1812 to 1857, the Romantic Era in Germany. To begin with, let us revisit how the prince is blinded, as recorded in the English translation by the noted Grimm's scholar, D. L. Ashliman:

On the evening of the same day that she sent Rapunzel away, the sorceress tied the cut-off hair to the hook at the top of the tower, and when the prince called out:

Rapunzel, Rapunzel,

Let down your hair.

She let down the hair.

The prince climbed up, but above, instead of his beloved Rapunzel, he found the sorceress, who peered at him with poisonous and evil looks.

"Aha!" she cried scornfully. "You have come for your Mistress Darling, but that beautiful bird is no longer sitting in her nest, nor is she singing any more. The cat got 
her, and will scratch your eyes out as well. You have lost Rapunzel. You will never see her again."

The prince was overcome with grief, and in his despair he threw himself from the tower. He escaped with his life, but the thorns into which he fell poked out his eyes. Blind, he wandered about in the forest, eating nothing but grass and roots, and doing nothing but weeping and wailing over the loss of his beloved wife. Thus he wandered about miserably for some years, finally happening into the wilderness where Rapunzel lived miserably with the twins that she had given birth to.

He heard a voice and thought it was familiar. He advanced toward it, and as he approached, Rapunzel recognized him, and crying, threw her arms around his neck. Two of her tears fell into his eyes, and they became clear once again, and he could see as well as before. He led her into his kingdom, where he was received with joy, and for a long time they lived happily and satisfied.

As can be seen, out of despair, the prince jumps from the tower when he finds that he has lost Rapunzel, who has been exiled by the old sorceress. He falls into the thorns, which poke his eyes out. The blinded prince then wanders the forest in search for Rapunzel. After living in total blindness for years, Rapunzel's voice brings him back to her. Reunited, Rapunzel weeps with joy as her tears fall into his eyes, they miraculously restore his sight. They live as a family, safe and sound in his kingdom, and the story ends in happiness, after considerable suffering.

In the Legenda Aurea (1275) (Le Franc 214), which many considered as the origin of the "maiden in the tower" archetype (Caprio 8; Eisfeld 44; De Vos 205), Saint Barbara is locked up in a tower by her wealthy pagan father, Dioscorus, who wants to protect Saint Barbara from suitors and the outside world. She prays to end her imprisonment, and eventually the tower wall opens and she escapes on her own. There is no prince, let alone any mentioning of blindness.

Similarly, in Mademoiselle de la Force's Persinette (1698), and in Giambattista Basile's "Petrosinella", a tale compiled in The Pentamerone (1634) ${ }^{1}$, blindness is absent although a prince exists. In the plots of these various versions, the focus is on secret meetings of the prisoner and the prince and their sexual relationship instead. The stories end with the prince helping the female protagonist escape from the tower. The prince then brings her home, they become man and wife, and the couple lives happily ever after. Throughout these versions, the prince does not experience blindness, or any misfortune.

The plot of Grimm's "Rapunzel" is similar to that of de la Force's Persinette (1698) and Basile's "Petrosinella" (1634) it apparent that the Grimm Brothers were influenced by some or at least one of these earlier versions when they wrote "Rapunzel". Yet, it is also obvious that they introduced significant changes. Firstly, unlike other versions where the suffering heroine is the focus of the story, in the Grimm's version, the suffering shifts to the prince. Secondly, as stated, the whole notion of blindness, had been added. As Sullivan points out, the Grimm's fairytales "we know and love today" are "the Brothers Grimm's written adaptation" (67). In other words, the Brothers did not faithfully record the collected oral folklore. The following section examines the historical and socio-cultural environment in which the Grimm Brothers lived and worked.

\section{THEROMANTICVISIONINGRIMM'SFAIRYTALES}

The Grimm Brothers, Jacob and Wilhelm Grimm, were born in 1785 and 1786 respectively in Hanau, Germany. There were nine children in their family, but only six managed to survive infancy. Just as Jacob became eleven years old, his father died, leaving his mother and the children in grief and poverty. The year 1796 was not just a dark moment for the family, but also a dark period for much of Europe. At that time, the German people, especially those of the lower classes, were subjected to exploitation and poor standards of living because of the rapid industrialization in Europe. Worst still, Germany was not a country, but a confederacy of 39 small to medium-size German states divided and occupied by the French during the Napoleonic Wars. Battlefields were everywhere. Cities were desolated. "The pleasure-gardens around the city were ravaged, the trees lining the avenues were chopped down." (Robertson xii - xiii). A major unifying factor for the Volk, i.e. the German people was their common language. With the desire "to gain a sense of their heritage and to strengthen the ties among themselves" (Zipes 68), in the early $19^{\text {th }}$ century, the German intellectuals developed a growing interest in the German language and its cultural origins during the Romantic Movement. This led to a wave of awakened interest in German folklore. To the intellectuals and romanticists, folklore embodied essential truths that were expressive and representative of the German people. They felt, somewhat rationalistically, that by collecting the folklore, the origins and truths about German customs, laws, culture and language could be preserved.

The Brothers Grimm were very much influenced by the Romantic Movement. They studied German linguistics and philosophical studies at university, worked as librarians for several years, and in about 1807, they joined the patriotic act of 'collecting' and rewriting folk tales. According to Schmiesing, the Grimm's fairytales, Kinder -und Hausmärchen (Children's and Household Tales) is a compilation of a "total of around 240 different tales... from about forty contributors and thirty written sources" (14). It is not surprising that many of the Grimm's fairy tales, including "Rapunzel", carry the spirit of German Romanticism. Themes such as anti-Enlightenment, anti-rationalism, anti-feudalism, anti-French, appear as celebrations of individualism and human imagination. A negation of the life-style of the emerging bourgeoisie, a protest against the utilitarian ordering of life to support further industry, and a tension between what Zipes calls "the forces of rationalism, utilitarianism and repression and the forces of creativity, imagination and freedom" (38) are also present in the fairy tales too. 


\section{THE FEMALE AS A SYMBOL OF IMAGINATION AND FREEDOM}

Under the influence of German Romanticism, the Grimm Brothers and their contemporaries held the view that "creative autonomy through the exercise of man's imaginative [...] powers" (Stahl et al 113-114) surpasses rational power and transcend reality. Romanticists believed that "the divine voice can be heard" (Manlove 145) only when reason, or what is called the "normal filters of the imagination" (ibid), is "suspended" (ibid). While feminist claims such as 'female sexuality is oppressed' (Lieberman 194) may hold for some Grimm's fairy tales, stories such as Grimm's "Rapunzel" have an inclination to portray, praise and glorify the female as a symbol of emotion, irrationality, imagination, sentiments and Nature, which were highly valued and cherished in German Romanticism. The female in the Grimm's tales is often associated with hope, salvation, divinity and nurturing Nature. Conversely, logic, rationality, the belief in empiricism, and the obsession with science are depicted as limitations of the male protagonist. To seek salvation, the male protagonist must give up his reason, and learn to understand, and trust the mystic power of imagination and emotion as represented by the female spirit (Tso, "Transgression in the gender representation" 14).

This is just like Anselmus, the male protagonist in The Golden Pot (1814), which was written by E. T. A. Hoffmann - a contemporary of the Brothers Grimm - at the end of the Napoleonic Wars when Hoffman was torn between the choices of being a lawyer or a writer. Anselmus, a bachelor, feels unhappy about the suffocating utilitarian principles advocated by the bourgeoisie. He cannot find his way in life until he meets Serpentina, the female spirit in the form of a green serpent. Serpentina teaches Anselmus about the power of imagination and irrationality, opening up a whole new world for him. With her help, Anselmus is in ecstasy, "Oh, let me see you twining and twisting and coiling in the branches just once more, you lovely green snake! Give me just one more glance from your lovely eyes! I love you, I love you, and if you do not return I must perish of sorrow and pain!" (the fourth vigil, 21) With Serpentina by his side, Anselmus discovers his extraordinary creative power as a writer, "I am a supremely happy man who has been granted supreme knowledge" (the twelfth vigil, 83). His newly found insight leads him out of the cage of the tedious, dehumanizing everyday life. In the same light, the prince in Grimm's "Rapunzel" relinquishes rationality and embraces the power of the female spirit - not once but twice did the prince follow the beauty of song, which eventually led him to a deep and complete human love. From a Romantic perspective, Anselmus in Hoffmann's The Golden Pot and the prince in Grimm's "Rapunzel" are exemplary male role models of emotional wisdom. They both trusted in their hearts; they seemed to instinctually know that "the scientific method can never fathom the mystery of life or answer fundamental moral questions such as why human beings are here, why we love, and why we suffer" (Kidner, Bucur, Mathisen, McKee \& Weeks 602). Ultimately, it is "the irrational - powerful emotions, the sense of beauty, the ecstasy of love" that "makes us human" (ibid). In summary, when feminist scholars criticize the genre of fairy tales for providing children with "the archetype of the suffering heroine" (Lieberman 194) and focusing too much on her "being beautiful, being chosen and getting rich" (ibid), they may have overlooked the key features of German Romanticism which the Grimm Brothers highlighted and advocated in the tale of "Rapunzel".

\section{BLINDNESS AS AN AWAKENING OF THE ROMANTIC VISION}

Grimm's "Rapunzel" is a fairy tale concerning a male giving up his over-reliance on reason and rationality, gradually learning to embrace irrationality, intuition, and the Romantic vision. As Pavlik-Malone suggests, the "magic" or "delight" (xxxi) in Grimm's "Rapunzel" embraces the life force in us: There is "magic" or "delight" in the story of Rapunzel that, for several reasons, embrace the four realms of "life". These include: the endurance of romantic love; the power of life over death; the strength of the spirit to heal; and the ability of dreams and inner visions to positively influence conscious experience. Thus, in having read this classic fairytale, and having identified with its key characters, one can feel inspiration, hope that life will always triumph over death. (Pavlik-Malone xxxi) Read the tale closely and one will find that the young prince, rather than Rapunzel, is the main character of the story (Tso, Female Sexuality in Grimm's Fairy Tales 11). As in Novalis' philosophical romance, the prince is the Romantic hero who wanders into the woods, mountains and other places in Nature, looking for the far-off, unattainable blue flower. At the beginning of the story, the prince knows of Rapunzel not by seeing her, but by being captivated by her song that fills the forest (and his heart), "...he heard a song so lovely that he stopped to listen. It was Rapunzel, who passes the time in her solitude by letting her sweet voice resound in the forest" (Translated by Zipes 48).

Mesmerized by the sweet voice, the prince follows his heart rather than reason. He trespasses to the old Dame Gothe's premises, breaking the law just to get close to the maiden who is trapped in the tower. His feelings brings him to the woman he loves. At first, the prince relies heavily on his sight and reason. His first attempt to get in touch with Rapunzel is by rational, empirical methods - not knowing how to go up the doorless, stairless tower he observes how the witch calls out to Rapunzel:

Rapunzel, Rapunzel,

Let down your hair. (Translated by Ashliman)

Having observed the secret method of getting up the tower, the prince remembers the two lines and learns them by heart. The next day, he waits till the sky darkens, returns to the tower, and then imitates the witch by calling out: 
Rapunzel, Rapunzel,

Let down your hair. (Translated by Ashliman)

As he expects, all at once the hair drops down, the prince climbs up, enters the tower and meets Rapunzel. Ever since then, day by day, he brings a piece of silk with him. He is so meticulous that he engineers the plan of weaving a ladder long enough to rescue Rapunzel from the imprisonment. However, instead of bringing him success and happiness, his faith in these scientific methods disappoints him. One fateful day, as the prince climbs up the tower, the old witch greets him instead. The woman he loves has been exiled and he is told that he will never see her again. In despair, he jumps off the tower. He has not lost his life, but the thorns below pierce his eyes, blinding him.

Here, the imagery of blindness is oxymoronic - while it may be a punishment for his exclusive dependence on sight and reason, it can also be a rebirth. Being freed from the limitation of sight, logical thinking and rationality, the prince becomes more alert to the invisible - the irrational, the Romantic vision, and the imaginative side of human mind, and heart. The prince experiences significant sufferings, but he learns the lesson that, as George MacDonald recounted, "it is not the things that we see the most clearly that influence us the most powerfully" (28), but those "undefined, yet vivid visions of something beyond, something which eye has not seen nor ear heard" (28), that "have far more influence than any logical sequences whereby the same things may be demonstrated to the intellect...It is the nature of the thing, not the clearness of its outline that determines its operation. We live by faith, and not by sight" (28).

As the blind prince wanders through his journey, his rational, empirical faith is increasingly replaced by the Romantic Vision. At the end of the story, his newly found insight leads him back to Rapunzel, "When he heard a voice that he thought sounded familiar, he went straight towards it, and when he reached her, Rapunzel recognized him" (Translated by Ashliman). His sight is restored when Rapunzel's tears drop into his blind eyes. The female spirit, "a symbol of good beauty" (Novalis 59), and a power of imagination and emotion, heals and completes him.

\section{CONCLUSION}

As a rereading Grimm's "Rapunzel", this paper has compared the earlier versions of "Rapunzel" with Grimm's version, created during a time of German nationalism and German Romanticism. It is found that the prince's blindness, a motif intentionally added by the Grimm Brothers, carries a strong Romanticist symbolism: while the loss of one's vision may bring suffering, the over-reliance on sight and reason is possibly a more debilitating 'blindness' to the creativity and imagination of the human mind. The loss of sight in "Rapunzel" is therefore not a punishment or deformity, but an awakening - a way to enter the Romantic Vision more deeply. Similar to Anselmus in Hoffmann's The Golden Pot, the prince is liberated when he trusts the imaginative, the irrational, the emotional - a typically female realm - and he is rewarded with a lasting love.

\section{END NOTES}

1. Basile, Giambattista. The Pentamerone. Trans. Benedetto Croce. New York: Dutton, 1932, Day 2, Tale 1.

\section{REFERENCES}

Basile, Giambattista. The Pentamerone. Trans. Benedetto Croce. New York: Dutton, 1932, Day 2, Tale 1.

Caprio, Betsy. The Woman Sealed in the Tower: Being a View of Feminine Spirituality as Revealed by the Legend of Saint Barbara. New York: Paulist Press, 1982.

De Vos, Gail, \& Altmann, Anna E. New Tales for Old: Folktales as Literary Fictions for Young Adults. Englewood, California: Libraries Unlimited, 1999.

Eisfeld, Conny. How Fairy Tales Live Happily Ever After: The Art of Adapting Fairy Tales. Hamburg: Anchor Academic Publishing, 2015.

Grimm, Jacob and Wilhelm Grimm. "Rapunzel." Grimm's Fairy Tales. Trans. Dan L. Ashliman. Folktexts: A Library of Folktales, Folklore, Fairy Tales, and Mythology. 7 Apr. 2015.

Hoffman, E. T. A. The Golden Pot and Other Tales. Trans. Ritchie Robertson. New York: Oxford University Press, 2000.

Jernigan, Kenneth. "Blindness: Is Literature Against Us?" National Federation of the Blind. Address at the Banquet of the Annual Convention. Chicago. 3 July 1974.

Keller, Helen. Helen Keller: The Story of My Life. New York: Watermill, 1980.

Kidner, Frank L., Maria Bucur, Ralph Mathisen, Sally McKee, and Theodore R. Weeks. Making Europe: The Story of the West, Since 1300. Boston: Wadsworth, Cengage Learning, 2014.

Le Franc, Martin. The Trial of Womankind: A Rhyming Translation of Book IV of the Fifteenth-Century Le Champion des Dames. Ed. and Trans. Steven Millen Taylor. Jefferson, North Carolina, and London: McFarland \& Company, Inc., Publishers, 2005.

Lieberman, Marcia R. "'Some day my prince will come': Female acculturation through the fairy tale." Don't Bet on the Prince: Contemporary Feminist Fairy Tales in North America and England. Ed. Jack Zipes. New York: Methuen, 1986. 383-395.

Manlove, Colin. "MacDonald and Kingsley: A Victorian Contrast." The Gold Thread: Essays on George MacDonald. Ed. William Raeper. Edinburgh: Edinburgh University Press, 1990. 140-162.

MacDonald, George. Orts. London: Sampson Low, Marston, Searle, and Rivington, 1882.

Novalis. Pollen and Fragments: Selected Poetry and Prose of Novalis. Trans. Arthur Versluis. Grand Rapids, MI: Phanes Press, 1989.

Robertson, Ritchie. "Introduction." The Golden Pot and Other Tales. Trans. Ritchie Robertson. New York: Oxford University Press, 2000. vii-xxxii.

Schmiesing, Ann. Disability, Deformity, and Disease in the Grimms' Fairy Tales. Detroit: Wayne State University Press, 2014. 
Sullivan, Kylee. “A Grimm Evolution.” Hohonu 14(2016): 67-69. Stahl, Ernest Ludwig and William Edward Yuill. German Literature of the Eighteenth and Nineteenth Centuries. New York: The Cresset Press Ltd, 1970.

Tso, Wing Bo. Female Sexuality in Grimm's Fairy Tales and Their English Translations. 2002. The University of Hong Kong, MA dissertation. HKU Scholars Hub, http://hub.hku.hk/handle/10722/39104.
"Transgression in the gender representation in MacDonald's Princess books." The International Journal of Early Childhood 39.2(2007): 11-21.

Zipes, Jack. Breaking the Magic Spells: Radical Theories of Folk and Fairy Tales. London: Heinemann, 1979.

- The Brothers Grimm: From Enchanted Forests to the Modern World. New York: Palgrave Macmillan, 2002. 